\title{
Negative Finding
}

National Cancer Institute

\section{Source}

National Cancer Institute. Negative Finding. NCI Thesaurus. Code C38757.

A finding of normality following an examination or investigation looking for the presence of a microorganism, disease, or condition. 